\title{
PENGARUH SUHU PENGERINGAN OVEN TERHADAP AKTIVITAS ANTIOKSIDAN BUBUK DAUN CEMCEM (Spondias pinnata (L.f) Kurz)
}

\author{
The Effect of Oven Drying Temperature on Antioxidant Activity of Cemcem Leaf Powder (Spondias \\ pinnata (L.f) Kurz) \\ ${ }^{1}$ I Putu Willigis Benito Khatulistiwa, ${ }^{2}$ I Dewa Gde Mayun Permana*, ${ }^{2}$ I Gusti Ayu Kadek Diah Puspawati \\ ${ }^{1}$ Mahasiswa Program Studi Ilmu dan Teknologi Pangan, Fakultas Teknologi Pertanian, Universitas Udayana \\ ${ }^{2}$ Dosen Program Studi Ilmu dan Teknologi Pangan, Fakultas Teknologi Pertanian, Universitas Udayana, \\ Kampus Bukit Jimbaran, Badung-Bali \\ Email: benitokhatulistiwa1708@gmail.com ${ }^{1}$
}

\begin{abstract}
This study aimed to determine the effect of oven drying temperature on the antioxidant activity of cemcem leaf powder and get the rightest oven drying temperature to produce cemcem leaf powder which had the highest antioxidant activity. The experimental design used was a completely randomized design with a drying temperature treatment consisting of consisting of 4 levels including: $40^{\circ} \mathrm{C}, 50^{\circ} \mathrm{C}, 60^{\circ} \mathrm{C}$ and $70^{\circ} \mathrm{C}$. The treatment was repeated 4 times to obtain 16 experimental units. The data obtained were analyzed using variance analysis, if it had a significant effect then it was continued with the Duncan Multiple Range Test (DMRT). The results showed the drying temperature had a very significant effect $(\mathrm{p}<0.01)$ on water content, total phenolic, total flavonoids and antioxidant activity. Drying temperature of $50^{\circ} \mathrm{C}$ is the best temperature to produce cemcem leaf powder with the highest antioxidant activity of $61.98 \%$ with $\mathrm{IC}_{50} 79.58 \mathrm{ppm}$, total phenolic $48.03 \mathrm{mg}$ GAE/g powder, total flavonoids 49.11 $\mathrm{mg} \mathrm{QE} / \mathrm{g}$ powder, water content $7.78 \%$.
\end{abstract}

Keywords: cemcem leaves, drying temperature, antioxidant activity.

\section{PENDAHULUAN}

Cemcem (Spondias pinnata (L.f.) Kurz) adalah tanaman yang termasuk ke dalam famili Anacardiaceae, tanaman ini hidup di daerah beriklim tropis dan subtropis. Cemcem merupakan tanaman yang masih berkerabat dekat dengan kedondong. Perbedaan tanaman ini dengan kedondong yaitu pada pucuk daun, pada cemcem pucuk daun berwarna hijau kemerahan sedangkan kedondong berwarna hijau (Manik et al., 2013).

Daun cemcem sering diolah sebagai minuman herbal yang berfungsi sebagai penambah nafsu makan (Ariati, 2012). Daun cemcem juga dimanfaatkan sebagai obat tradisonal untuk mengatasi penyakit batuk, diare, sakit perut, rematik, diabetes, dan demam (Hutapea, 1994, Bora et al., 2014). Pemanfaatan daun cemcem tersebut disebabkan jumlah dan jenis komponen kimia yang terkandung di dalamnya. Das et al., (2011) melaporkan bahwa daun cemcem mengandung asam amino, vitamin $\mathrm{C}$, mineral, protein, saponin, tanin dan flavonoid. Menurut Satpathy et al., (2011) bahwa daun cemcem merupakan sumber yang kaya dengan fenolik dan flavonoid. Fenolik dan flavonoid dapat berfungsi sebagai antioksidan (Lee et al., 2004).

Pemanfaatan daun cemcem selama ini umumnya dalam bentuk segar. Dalam bentuk segar cemcem akan cepat layu, mudah membusuk, dan tidak dapat disimpan dalam waktu yang lama. Upaya untuk mengatasi hal tersebut dapat melalui proses pengeringan. Pengeringan adalah proses pengeluaran air dalam jumlah tertentu dari suatu zat padat atau semi padat melalui penguapan (Greensmith,1998). Pengeringan bertujuan untuk mendapatkan bahan yang tidak mudah rusak, sehingga dapat disimpan dalam waktu yang lebih lama. Metode dalam pengeringan ada beberapa yaitu 
pengeringan dengan sinar matahari langsung, pengeringan dengan oven, dan kering angin (Pramono, 2006). Menurut Winangsih (2013), penggunaan oven pada pengeringan bubuk Lempuyang Wangi (Zingiber aromaticum L.) merupakan yang terbaik dibandingkan dengan pengeringan menggunakan sinar matahari dan kering angin. Pengeringan dengan oven dianggap lebih menguntungkan karena akan terjadi pengurangan kadar air dalam jumlah besar dalam waktu yang singkat (Muller et al., 2006)

Proses pengeringan oven dapat dipengaruhi oleh suhu. Penggunaan suhu yang tinggi dapat mengakibatkan terjadinya perubahan komponen bioaktif sehingga mengurangi kualitas bubuk kering lempuyang wangi (Pramono, 2006). Andarwulan et al., (1996), melaporkan pemanasan yang cukup lama dan menggunakan temperatur yang tinggi dapat menurunkan aktivitas antioksidan. Pengeringan pada suhu yang rendah akan mengakibatkan lamanya waktu pengeringan, mengalami pembusukan, dan aktivitas antioksidan yang dihasilkan rendah akibat belum inaktifnya enzim polifenol oksidase.

Beberapa penelitian mengenai pengaruh suhu pengeringan dalam pengolahan bubuk terhadap kandungan bioaktifnya telah dilakukan seperti pada penelitian Sidoretno (2018) melaporkan aktivitas antioksidan daun matoa (pometia pinnata) dengan variasi suhu pengeringan $30^{\circ} \mathrm{C}$, $60^{\circ} \mathrm{C}$, dan $90^{\circ} \mathrm{C}$. Suhu $60^{\circ} \mathrm{C}$ merupakan perlakuan terbaik yang mengasilkan $\mathrm{IC}_{50}$ terendah atau kemampuan aktivitas antioksidan kuat pada daun matoa. Hihat et al., (2017) melaporkan pengeringan daun kerumbar dengan variasi suhu pengeringan $40^{\circ} \mathrm{C}-120^{\circ} \mathrm{C}$, total fenolik tertinggi diperoleh pada suhu $60^{\circ} \mathrm{C}$ dengan waktu 160 menit. Lemus et al., (2016) melaporkan efek suhu pereringan terhadap kandungan bioaktif dan aktifitas antioksidan daun stevia yang menggunakan variasi suhu pengeringan $30^{\circ} \mathrm{C}$ $80^{\circ} \mathrm{C}$, dengan aktivitas antioksidan tertinggi pada suhu $40^{\circ} \mathrm{C}$. Gálvez et al., (2009) melaporkan efek suhu pengeringan oven terhadap aktifitas antioksidan dan total fenolik cabai merah (Capsicum annuum $\mathrm{L}$ ) yang menggunakan variasi suhu $40^{\circ} \mathrm{C}-90^{\circ} \mathrm{C}$, dengan aktivitas antioksidan dan total fenolik tertinggi terdapat pada suhu $60^{\circ} \mathrm{C}$. Pada pengeringan beberapa daun menggunakan variasi suhu mendapatkan suhu optimum yang berbeda, oleh karena itu perlu dilakukan penelitian terhadap variasi suhu pengeringan pada pembuatan bubuk daun cemcem untuk mendapatkan suhu pengeringan yang tepat sehingga diperoleh bubuk daun cemcem dengan aktifitas antioksidan yang tertinggi.

\section{METODE PENELITIAN}

\section{Tempat dan Waktu}

Penelitian ini dilaksanakan di Laboratorium Analisis Pangan, Laboratorium Pengolahan Pangan, Program Studi Ilmu dan Teknologi Pangan, Fakultas Teknologi Pertanian, Universitas Udayana, Kampus Sudirman, Denpasar, Bali. Pelaksanaan penelitian ini dilakukan pada bulan Juli 2019 sampai dengan bulan September 2019.

\section{Bahan dan Alat}

Bahan yang digunakan dalam penelitian ini adalah daun cemcem muda dengan karakteristik daun berwarna hijau muda dari tangkai ke 4 sampai tangkai ke 10, diperoleh dari Desa Cau Belayu, Tabanan. Bahan kimia yang digunakan meliputi: aquades, etanol $70 \%$, sodium karbonat (Merck), reagen Folin-Ciocalteu (Merck), $\mathrm{NaNO}_{2}, \quad \mathrm{AlCl}_{3}, \quad \mathrm{NaOH}$ (Merck), DPPH (Diphenylpicryl-hydrazyl) (Himedia), standar kuersetin (Sigma), dan standar asam galat (Sigma).

Alat-alat yang digunakan pada penelitian ini yaitu oven (Blue $M$ ), loyang, aluminium foil, pinset, timbangan analitik (Shimadzu), Orbital shaker, cawan aluminium, labu ukur, gelas beker (Pyrex), gelas ukur (Herma), tabung reaksi (Pyrex), pipet tetes, blender (Miyako), spektrofotometer (Biochrom Libra S70PC Double Beam), mikropipet (Thermo 
Scientific), desikator, erlenmeyer (Pyrex), kuvet (Biochrom), pompa karet, tip, kertas saring whatman no. 1, vortex (Maxi Mix II Type 367000), ayakan 60 mesh.

\section{Rancangan Percobaan}

Penelitian ini menggunakan Rancangan Acak Lengkap (RAL) dengan perlakuan suhu pengeringan. Suhu pengeringan terdiri dari 4 level meliputi:

S1: Suhu pengeringan $40^{\circ} \mathrm{C}$

S2: Suhu pengeringan $50^{\circ} \mathrm{C}$

S3: Suhu pengeringan $60^{\circ} \mathrm{C}$

S4: Suhu pengeringan $70{ }^{\circ} \mathrm{C}$

Perlakuan ini diulang sebanyak empat kali sehingga diperoleh 16 unit percobaan. Data yang diperoleh dianalisis secara statistik menggunakan sidik ragam, Jika berpengaruh nyata maka dilanjutkan dengan Duncan Multiple Range Test (DMRT), dengan menggunakan program SPSS 25 (Steel dan Torrie, 1993).

\section{Pelaksanaan Penelitian}

Daun cemcem ditimbang sebanyak $100 \mathrm{~g}$, dibersihkan dengan air mengalir untuk menghilangkan kotoran, setelah itu ditiriskan, lalu dikeringkan menggunakan oven sesuai dengan perlakuan $\left(40^{\circ} \mathrm{C}, 50^{\circ} \mathrm{C}\right.$, $60^{\circ} \mathrm{C}, 70^{\circ} \mathrm{C}$ ) selama 24 jam (kriteria daun cemcem kering dan mudah dipatahkan), kemudian dihaluskan menggunakan blender dan diayak dengan ayakan ukuran 60 mesh (Widarta dan Arnata, 2017). Bubuk yang telah diayak tersebut kemudian ditimbang. Diagram alir tahapan pembuatan bubuk daun cemcem dapat dilihat pada Gambar 1.

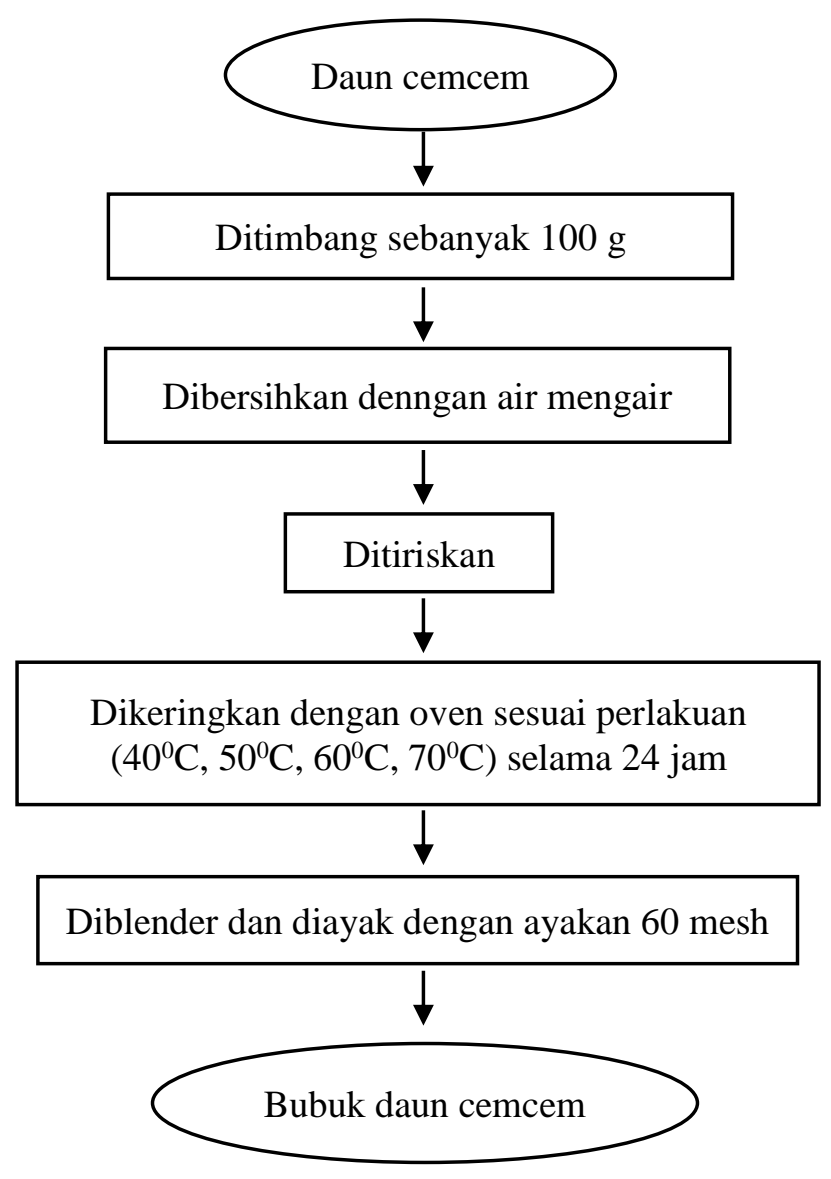

Gambar 1. Diagram alir pembuatan bubuk daun cemcem (Widarta dan Arnata, 2017), yang dimodifikasi 


\section{Variabel yang Diamati}

Variabel yang diamati dalam penelitian bubuk daun cemcem meliputi: kadar air dilakukan dengan metode pengeringan oven (AOAC, 2005), total fenolik dilakukan menggunakan reagen Folin-Ciocalteau (Ghasemzadeh et al., 2012), total flavonoid (Ghasemzadeh et al.,2012), dan aktivitas antioksidan dengan 2,2 - dipheny 1 - 1 picrylhydrazyl (DPPH) (Vasic et al.,2012).

\section{HASIL DAN PEMBAHASAN}

Nilai rata-rata kadar air, total fenolik, flavonoid, dan aktivitas antioksidan bubuk daun cemcem dapat dilihat pada Tabel 1 .

Tabel 1. Nilai rata - rata kadar air, total fenolik, flavonoid, dan aktivitas antioksidan bubuk daun cemcem.

\begin{tabular}{ccccc}
\hline Suhu & Kadar Air $(\%)$ & $\begin{array}{c}\text { Total Fenolik }(\mathrm{mg} \\
\text { GAE/g bubuk) }\end{array}$ & $\begin{array}{c}\text { Flavonoid (mg QE/g } \\
\text { bubuk) }\end{array}$ & $\begin{array}{c}\text { Aktivitas } \\
\text { Antioksidan }(\%)\end{array}$ \\
\hline S1 & $8,77 \pm 0,03 \mathrm{a}$ & $34,58 \pm 1,24 \mathrm{c}$ & $34,78 \pm 2,15 \mathrm{c}$ & $56,91 \pm 1,27 \mathrm{~b}$ \\
S2 & $7,88 \pm 0,09 \mathrm{~b}$ & $48,04 \pm 1,33 \mathrm{a}$ & $49,11 \pm 1,34 \mathrm{a}$ & $61,98 \pm 1,09 \mathrm{a}$ \\
S3 & $7,69 \pm 0,04 \mathrm{c}$ & $45,07 \pm 0,79 \mathrm{~b}$ & $46,17 \pm 0,76 \mathrm{~b}$ & $59,47 \pm 0,59 \mathrm{ab}$ \\
S4 & $7,24 \pm 0,03 \mathrm{~d}$ & $25,81 \pm 1,22 \mathrm{~d}$ & $33,03 \pm 2,11 \mathrm{c}$ & $38,20 \pm 2,88 \mathrm{c}$ \\
\hline
\end{tabular}

Keterangan: Huruf berbeda di belakang nilai rata- rata pada kolom yang sama menunjukan perbedaan yang nyata $(p<0,05)$.

\section{Kadar Air}

Hasil penelitian menunjukkan bahwa suhu pengeringan berpengaruh sangat nyata $(p<0,01)$ terhadap kadar air bubuk daun cemcem. kadar air bubuk daun cemcem berkisar antara 7,24\% $8,77 \%$. Kadar air terendah bubuk daun cemcem diperoleh pada perlakuan suhu pengeringan $70^{\circ} \mathrm{C}$ (S4) sebesar 7,24 \%, sedangkan kadar air tertinggi bubuk daun cemcem diperoleh pada perlakuan suhu pengeringan $40^{\circ} \mathrm{C}(\mathrm{S} 1)$ sebesar $8,77 \%$. Hasil penelitian ini menunjukkan semakin tinggi suhu pengeringan, semakin kecil kadar air bubuk daun cemcem yang dihasilkan. Kadar air bubuk cemcem tersebut memenuhi syarat kadar air bubuk, berdasarkan anon (2008) yang menyatakan kadar air pada bubuk tidak lebih dari 10\%. Taib et al, (1988) menyatakan semakin tinggi suhu selama proses pengeringan, maka semakin besar energi panas sehingga makin banyak jumlah air yang diuapkan dari permukaan bahan yang dikeringkan. Menurut Winarno (1995), semakin tinggi suhu pengeringan maka semakin cepat terjadi penguapan, sehingga kandungan air di dalam bahan semakin rendah. Dewi (2017) melaporkan bahwa semakin tinggi suhu pengeringan pada daun katuk kadar air yang dihasilkan akan semakin kecil.

\section{Total Fenolik}

Hasil penelitian menunjukkan bahwa suhu pengeringan berpengaruh sangat nyata $(p<0,01)$ terhadap kandungan total fenolik bubuk daun cemcem. Total fenolik bubuk daun cemcem tertinggi diperoleh pada suhu pengeringan $50^{\circ} \mathrm{C}$ (S2) yaitu 48,03 mg GAE/g bubuk, sedangkan total fenolik terendah bubuk daun cemcem diperoleh pada suhu pengeringan $70^{\circ} \mathrm{C}(\mathrm{S} 4)$ yaitu 25,81 mg GAE/g bubuk. Hasil penelitian menunjukkan total fenolik mengalami peningkatan dari suhu $40^{\circ} \mathrm{C}$ ke suhu $50^{\circ} \mathrm{C}$, kemudian mengalami penurunan pada suhu $60^{\circ} \mathrm{C}$ dan $70^{\circ} \mathrm{C}$. Total fenolik meningkat dari $40^{\circ} \mathrm{C}$ ke suhu $50^{\circ} \mathrm{C}$ disebabkan karena inaktivnya enzim polifenol oksidase. Total fenolik setelah suhu $50{ }^{\circ} \mathrm{C}$ disebabkan oleh panas yang tinggi melewati suhu optimum dapat menyebabkan terjadinya kerusakan terhadap komponen bioaktif seperti fenolik. Chu dan Juneja (1997) melaporkan senyawa polifenol merupakan senyawa yang rentan terhadap panas. Susanti (2008) melaporkan bahwa kandungan fenolik 
pada daun gambir kering akan meningkat sampai suhu $50^{\circ} \mathrm{C}$ kemudian cenderung menurun.

\section{Total Flavonoid}

Hasil penelitian menunjukkan bahwa suhu pengeringan berpengaruh sangat nyata $(p<0,01)$ terhadap kandungan total flavonoid bubuk daun cemcem. Total flavonoid bubuk daun cemcem tertinggi diperoleh pada suhu pengeringan $50^{\circ} \mathrm{C}$ (S2) yaitu 49,11 mg QE/g bubuk, sedangkan total flavonoid terendah bubuk daun cemcem diperoleh pada suhu pengeringan $70^{\circ} \mathrm{C}(\mathrm{S} 4)$ yaitu $33,02 \mathrm{mg}$ GAE/g bubuk. Hasil penelitian menunjukkan total flavonoid meningkat dari suhu $40^{\circ} \mathrm{C}$ hingga suhu $50^{\circ} \mathrm{C}$, kemudian mengalami penurunan pada suhu $60^{\circ} \mathrm{C}$ dan $70^{\circ} \mathrm{C}$. Total fenolik mengalami peningkatan pada suhu $50^{\circ} \mathrm{C}$ disebabkan karena inaktivnya enzim polifenol oksidase. Total flavonoid menurun pada suhu yang tinggi karena memiliki sifat yang mudah teroksidasi. Syafarina et al., (2017) menyatakan bahwa flavonoid merupakan golongan polifenol dengan struktur dasar fenol yang senyawanya memiliki sifat mudah teroksidasi dan sensitif terhadap perlakuan panas sehingga dengan adanya panas pada saat pengeringan akan mempengaruhi kadar flavonoid. Sekarini (2011) melaporkan bahwa suhu pengeringan $65^{\circ} \mathrm{C}$ akan mengakibatkan terjadinya oksidasi komponen polifenol.

\section{Aktivitas Antioksidan}

Hasil penelirian menunjukkan bahwa suhu pengeringan berpengaruh sangat nyata $(p<0,01)$ terhadap kandungan aktivitas antioksidan bubuk daun cemcem. Aktivitas antioksidan bubuk daun cemcem tertinggi diperoleh pada suhu pengeringan $50^{\circ} \mathrm{C}(\mathrm{S} 2)$ yaitu $61,98 \%$, sedangkan aktivitas antioksidan terendah bubuk daun cemcem diperoleh pada suhu pengeringan $70^{\circ} \mathrm{C}$ (S4) yaitu 38,19\%. Hasil penelitian menunjukan aktivitas antioksidan bubuk daun cemcem meningkat dari suhu $40^{\circ} \mathrm{C}$ hingga suhu $50^{\circ} \mathrm{C}$ kemudian mengalami penurunan pada suhu $60^{\circ} \mathrm{C}$, dan $70^{\circ} \mathrm{C}$. Aktivitas antioksidan seiring dengan hasil total fenolik dan total flavonoid, yang mengalami peningkatan hingga suhu $50^{\circ} \mathrm{C}$ dan kemudian menurun. Aktivitas antioksidan bubuk daun cemcem dipengaruhi oleh kadar total fenolik dan flavonoid. Total fenolik dan flavonoid merupakan senyawa yang memiliki kemampuan sebagai antioksidan. Menurut Lee et al., (2004) bahwa fenolik dan flavonoid dapat bersifat sebagai antioksidan karena kemampuannya mendonorkan atom hydrogen kepada radikal bebas, dan sebagai pengikat logam.

Penelitian yang dilakukan oleh Sayekti (2016) menyatakan bahwa aktivitas antioksidan pada kombinasi teh daun katuk dan daun kelor akan menurun apabila suhu pengeringan melebihi $\quad 50^{\circ} \mathrm{C}$. Pengeringan yang menggunakan suhu yang tinggi dapat menyebabkan turunnya aktivitas antioksidan, karena komponen - komponen penyusun antioksidan seperti fenolik dan flavonoid mudah teroksidasi (Andarwulan et al.,1996). Hasil penelitian ini sesuai dengan hasil penelitian Dewi (2017), yang melaporkan suhu $50^{\circ} \mathrm{C}$ sebagai perlakuan terbaik yang menghasilkan aktivitas antioksidan tertinggi.

Nilai $\mathrm{IC}_{50}$ diperoleh pada konsentrasi 79,58 ppm. Nilai IC $_{50}$ yang semakin kecil, menunjukkan kemampuan antioksidan yang lebih tinggi dalam menangkal radikal bebas. Nilai $\mathrm{IC}_{50}$ bubuk daun cemcem dapat digolongkan sebagai bahan yang memiliki sifat antioksidan yang kuat. Blois (1958) menyatkan bahwa bahan yang memiliki nilai $\mathrm{IC}_{50}$ sebesar 50-100 ppm memiliki sifat antioksidan yang kuat (Blois, 1958).

\section{KESIMPULAN DAN SARAN}

\section{Kesimpulan}

Berdasarkan hasil penelitian ini dapat disimpulkan sebagai berikut:

1. Suhu pengeringan dengan oven pada bubuk daun cemcem berpengaruh sangat nyata terhadap kadar air, total fenolik, total flavonoid, dan aktivitas antioksidan.

2. Suhu pengeringan $50^{\circ} \mathrm{C}$ merupakan perlakuan terbaik yang menghasilkan bubuk daun cemcem dengan aktivitas antioksidan tertinggi sebesar $61,98 \%$ dengan $\mathrm{IC}_{50} 79,58$ ppm, total 
fenolik 48,03 mg GAE/g bubuk, total flavonoid 49,11 mg QE/g bubuk, dan kadar air 7,78\%.

\section{Saran}

Berdasarkan hasil penelitian ini disarankan untuk:

1. Menggunakan suhu pengeringan $50^{\circ} \mathrm{C}$ dalam proses pembuatan bubuk daun cemcem.

2. Perlu dilakukan penelitian lebih lanjut terkait optimasi waktu pengeringan pada suhu $50^{\circ} \mathrm{C}$.

\section{DAFTAR PUSTAKA}

Andarwulan, N., H. Wijaya, dan D.T. Cahyono.1996. Aktivitas antioksidan dari daun sirih (Piper betle L). Teknologi dan Industri Pangan, 29-30.

Anonimus. 2008. Farmakope Herbal Indonesia. Departemen Kesehatan Republik Indonesia. Jakarta.

AOAC. 2005. Official Method of Analysis of Association Official Agriculture Chemist, Washington DC.

Ariati, N.K. 2012. Aktivitas bakterisida ekstrak cemcem (Spondias Pinnata (L .F) Kurz) terhadap bakteri erwinia chrysanthemi penyebab penyakit busuk lunak lidah buaya. Jurnal Kimia, 6 (1): 88-92

Blois, M.S. 1958. Antioxidant determinations using a stable free radical. Nature, 181:1199-1200.

Bora, N.S., B.B Kakoti, B. Gogoi, and A.K Goswami. 2014. Ethno-medicinal claims, phytochemistry and pharmacology of Spondias pinnata - a review. International Journal Pharmaceu Sci Res, 5: 1138-1145.

Chu, D. C dan L. R. Juneja. 1997. General chemical composition of green tea and its infusion chemistry and applications of green tea. CRC Press LLC. USA, 13- 21.

Das, J. A. M, Md. M. Rahman, Md. A. M. Dinar, M.E. Uddin, I. N. Khan, and Md. R. H. N. Hasan. 2011. Chloroform and ethanol extract of Spondias pinnata and its different pharmacological activity like antioxidant, cytotoxic, antibacterial potential and hytochemical screening through in vitro method. International Journal of Research in Pharmaceutical and Biomedical Sciences, 2(4):1805 1812.

Dewi, W. K, N. Harun, dan Y. Zalfiatri. 2017. Pemanfaatan daun katuk (Sauropus adrogynus) dalam pembuatan teh herbal dengan variasi suhu pengeringan. Jurnal Online Mahasiswa Bidang Pertanian, 4(2): 1-9.

Gálvez, A., M. Miranda, H. Maureira, K. Rodriguez, and Vega. 2009. Effect of airdrying temperature on physico-chemical properties, antioxidant capacity, colour and total phenolic content of red pepper (Capsicum апnиит, L. var. Hungarian). Journal of Food Chemistry, 117: 647-653.

Ghasemzadeh, A., 2012. Polyphenolic content and their antioxidant activity in leaf extract of sweet potato (Ipomoea batatas). Journal of Medicinal Plants Research, 6(15): 29712976.

Hihat, S., H. Remini, and K. Madani. 2017. Effect of oven and microwave drying on phenolic compounds and antioxidant capacity of coriander leaves. International Food Research Journal, 24(2): 503-509.

Hutapea, J. R. 1994. Inventaris Tanaman Obat Indonesia, Jilid III, Departemen Kesehatan RI dan Badan Penelitian dan Pengembangan Kesehatan, Jakarta.

Lee, J., N. Koo, and D. B. Min. 2004. Reactive oxygen species, aging, and antioxidative nutrceuticals. Comprehensive Reviews in Food Science and Food Safety, 3: 21-33.

Lemus, M., R. K. Ah-Hen, A. V. Gálvez, C. Honores, and N. O. Moraga. 2016. Stevia rebaudiana leaves: effect of drying process 
temperature on bioactive components, antioxidant capacity and natural sweeteners. Plant Foods for Human Nutrition, 71(1) : 49-56.

Manik, M. K., S. Islam, M. A. Wahid, M. M. Morshed, S. Kamal, and K. T. Ahmed. 2013. Investigation of in vitro antioxidant, antimicrobial and thrombolytic activity of the exocarp of Spondias pinnata (Anacardiaceae). Can Chem T, 1(3): 191-201.

Muller, J. and A. Heindl. 2006. Drying of medicinal plants In R.J. Bogers, L.E. Craker, and D. Lange (eds.), Medicinal and Aromatic Plants, Springer, The Netherlands, 237-252.

Satpathy, G., Y. K. Tyagi., and R. K. Gupta., 2011. Preliminary evaluation of nutraceutical and therapeutic potential of raw Spondias pinnata K., an exotic fruit of India. Food Research International, 44(7):2076-2087.

Sayekti, D. 2016. Aktivitas antioksidan teh kombinasi daun katuk dan daun kelor dengan variasi suhu pengeringan. Skripsi. Universitas Muhammadiyah. Surakarta.

Sekarini, G. A. 2011. Pengaruh Suhu Pengeringan Terhadap Kadar Total Fenol, Kadar Tanin (Katekin) dan Aktivitas Antioksidan pada Minuman Teh Hijau (Camellia sinensis L.). Skripsi. Jurusan Teknologi Hasil Pertanian. Universitas Sebelas Maret, Surakarta.

Sidoretno, W. M., dan U. Abdurrab. 2018. Aktivitas antioksidan daun matoa ( pometia pinnata) dengan variasi suhu pengeringan, 3(1): 16-25.

Steel, R.G.D dan J.H. Torrie. 1993. Prinsip Dan Prosedur Statistika Suatu Pendekatan Biometrik. Penerjemah B. Sumantri. PT. Gramedia Pustaka, Jakarta.
Susanti, D.Y. 2008. Efek Suhu Pengeringan terhadap Kandungan Fenolik dan Kandungan Katekin Ekstrak Daun Kering Gambir. Prosiding Seminar Nasional Teknik Pertanian Universitas Gadjah Mada, Yogyakarta.

Syafarina, M., Irham, dan T. Edyson. 2017. Perbedaan Total Flavonoid antara Tahapan Pengeringan Alami dan Buatan pada Ekstrak Daun Binjai (Mangifera caesia). Skripsi. Fakultas Kedokteran Gigi Univ. Lambung Mangkurat, Banjarmasin.

Taib ,G., E.G. Sa'id, dan S. Wiraatmaja. 1988. Operasi Pengeringan Pada Pengolahan Hasil Pertanian, Mediyatama Sarana Perkasa, Jakarta.

Pramono, S. 2006. Penanganan pasca panen dan pengaruhnya terhadap efek terapi obat alami. Prosiding Seminar nasional Tumbuhan Obat Indonesia XXVIII. Bogor, 15-18.

Vasić, S. M., O. D. Stefanović, B. Z Ličina, I. D. Radojević, and L. R. Čomić. 2012. Biological activities of extracts from cultivated granadilla Passiflora alata. EXCLI Journal, 11: 208-218.

Widarta, I. W. R dan I. W. Arnata. 2017. Ekstraksi komponen bioaktif daun alpukat dengan bantuan ultrasonik pada berbagai jenis dan konsentrasi pelarut. Jurnal Agritech, 37(2): 148-157.

Winangsih. 2013. Pengaruh metode pengeringan terhadap kualitas simplisia lempuyang wangi (Zingiber aromaticum L.). Laboratorium Biologi Struktur dan Fungsi Tumbuhan Jurusan Biologi, Fakultas Sains dan Matematika, Universitas Diponegoro, Tembalang, Semarang, 19-25.

Winarno, F. G. 1995. Kimia Pangan dan Gizi. Gramedia Pustaka Utama, Jakarta. 